\title{
KARAKTER TOKOH DALAM ANTOLOGI CERPEN MATA YANG ENAK DIPANDANG KARYA AHMAD TOHARI DAN IMPLIKASINYA
}

\author{
'Zulfatun Maghfiroh; ${ }^{2}$ Tri Mulyono; ${ }^{3}$ Vita Ika Sari \\ 1,2,3 Program Studi Ilmu Pendidikan Sastra Indonesia FKIP \\ Universitas Pancasakti Tegal
}

\section{Abstrak}

\section{Korespondensi: riskalubisikariska97@gmail.com}

Permasalahan dalam penelitian ini adalah bagaimana karakter tokoh antologi cerpen Mata yang Enak Dipandang karya Ahmad Tohari dan Implikasinya. Tujuan penelitian ini adalah mendeskripsikan karakter tokoh antologi cerpen Mata yang Enak Dipandang karya Ahmad Tohari dan implikasinya. Wujud data penelitian berupa kutipan kalimat yang menggambarkan karakter yang terdapat pada tokoh-tokohnya. Metode penelitian yang digunakan dalam penelitian ini adalah metode deskriptif kualitatif. Sedangkan teknik pengumpulan data dalam penelitian ini menggunakan simak, baca dan catat. Teknik analisis data yang digunakan adalah teknik ekspositori dan teknik dramatik. Kemudian teknik penyajian hasil analisis datanya dengan mendeskripsikan data yang telah diperoleh pada penelitian yang ditelah dilakukan. Hasil penelitian ditemukan 28 karakter yang berbeda-beda pada setiap tokohnya dengan tiga karakter yang lebih dominan muncul ialah, karakter pemarah ditemukan pada tiga cerpen, yaitu "Mata yang Enak Dipandang", "Sayur Bleketupuk", dan "Dawir, Turah, dan Tolol", karakter peduli ditemukan pada cerpen "Bila Jebris ada di Rumah Kami", dan "Harta Gantungan", dan Karakter baik hati ditemukan pada cerpen "Bila Jebris Ada di Rumah Kami" dan "Sayur Bleketupuk" dalam antologi cerpen Mata yang Enak Dipandang Karya Ahmad Tohari.

Kata Kunci: karakter tokoh, cerpen, implikasi

\begin{abstract}
This study discusses the characters in the short story anthology Mata yang Enak Dipandang by Ahmad Tohari and implications. The purpose of this study is to describe the character of the characters and their implications in the anthology Mata yang Enak Dipandang short story by Ahmad Tohari. The form of research data is in the form of sentence quotes that describe the characters found in the characters. The research method used in this research is descriptive qualitative method. While the data collection techniques in this study use listening, reading and note taking. The data analysis technique used is expository and dramatic techniques. Then the technique of presenting the results of data analysis by describing the data that has been obtained in the research that has been done. The results of the study found 28 different characters in each character with three more dominant characters appearing, a grumpy character found in three short stories, namely "Mata yang Enak Dipandang", "Sayur Bleketupuk", and "Dawir, Turah, and Totol" , caring characters are found in the short stories "Bila Jebris ada di Rumah Kami", dan "Harta Gantungan", and the benevolent character is found in the short stories "Bila Jebris
\end{abstract}


Ada di Rumah Kami" dan "Sayur Bleketupuk" in the anthology of short stories Mata yang Enak Dipandang by Ahmad Tohari's work.

Keywords: Characters, short stories, implication

\section{PENDAHULUAN}

Karya sastra merupakan penggambaran kehidupan manusia yang diciptakan oleh pengarang. Salah satu jenis karya sastra yaitu cerpen. Cerpen atau cerita pendek di dalamnya terdapat amanat yang dapat diambil sebagai pelajaran bagi pembacanya. Menurut menurut (Wiyanto, 2005:100), cerpen (cerita pendek) adalah karangan berbentuk prosa. Dalam cerpen dikisahkan sepenggal kehidupan tokoh (pelaku) yang penuh pertikaian, dan penuh peristiwa yang mengharukan atau menyenangkan. Di samping itu, di dalam cerpen terdapat kesan yang tidak mudah dilupakan. Sedangkan menurut (Nugrahaeni, 2012:253) cerpen merupakan prosa yang berbentuk naratif fiktif. Naratif fiktif adalah sebuah karya sastra yang menjelaskan mengenai hal yang besifat fiktif atau khayalan.

Sebuah cerpen tentunya memiliki unsur-unsur pembangun dalam penceritaannya. Salah satu unsur yang sangat penting keberadaannya adalah unsur tokoh. Setiap tokoh yang ditampilkan dalam cerpen memiliki karakter yang berbeda-beda dalam menghidupkan cerita agar amanat yang disampaikan pengarang dapat dipahami oleh pembaca dengan baik. Sehingga, pembelajaran sastra di SMA, khususnya yang berkaitan dengan karakter tokoh dapat dijadikan pilihan bagi guru dalam mengajarkan serta memberi arahan terhadap siswa tentang karakter yang baik dan tidak jika diterapkan dalam kehidupan sehari-hari.

Dilihat dari perkembangan zaman saat ini, yang mana masalah moral semakin hilang, pembelajaran karakter melalui tokoh dalam cerpen dapat mempermudah seorang guru dalam pembentukan karakter siswa. (Sudjiman, 1991:16) berpendapat tokoh ialah individu rekaan yang mengalami peristiwa atau perlakuan di dalam berbagai peristiwa cerita.

Menurut (Nurgiyantoro, 2013: 247) istilah tokoh menunjuk pada orang atau pelaku cerita. (Nurgiyantoro, 2013: 258-278) juga membagi tokoh menjadi beberapa macam, yaitu tokoh utama dan tokoh tambahan, tokoh protagonis dan tokoh antagonis, tokoh sederhana dan tokoh bulat, tokoh statis dan tokoh berkembang, dan tokoh tipikal dan tokoh netral. Sedangkan karakter tokoh adalah watak yang dimiliki oleh tokoh-tokoh yang ditampilkan pengarang dalam sebuah cerita. (Stanton, 2012:33) mengemukakan bahwa karakter biasanya dipakai dalam dua konteks. Pada konteks pertama, karakter merujuk pada individu-individu yang muncul dalam cerita seperti ketika ada orang yang bertanya, "Berapa karakter yang ada dalam cerita itu?". Sedangkan konteks yang kedua, karakter merujuk pada percampuran dari berbagai kepentingan, keinginan, emosi, dan prinsip moral dari individu-individu tersebut seperti yang tampak implisit pada pertanyaan, "Menurutmu, bagaimanakah karakter dalam cerita itu?".

Antologi cerpen Mata yang Enak Dipandang karya Ahmad Tohari memiliki ciri khas, yaitu cerita yang diangkat mengisahkan kehidupan orang-orang kalangan bawah, sehingga memiliki ketertarikan tersendiri, khususnya bagi pembaca. Antologi cerpen karya pengarang Ronggeng Dukuh Paruk itu di dalamnya terdapat lima belas judul cerpen, yaitu: (1) "Mata yang Enak Dipandang", (2) "Bila Jebris ada Di Rumah Kami", (3) "Penipu yang Keempat", (4) "Daruan", (5) "Warung Panajem", (6) "Paman Doblo 
Merobek Layang-Layang", (7) "Kang Sarpin Minta Dikebiri”, (8) "Akhirnya Karsim Menyeberang Jalan", (9) "Sayur Bleketupuk", (10) "Rusmi ingin Pulang", (11) "Dawir, Turah, dan Totol", (12) "Harta Gantungan", (13) "Pemandangan Perut", (14) "Salam dari Penyangga Langit", dan (15) "Bulan Kuning Sudah Tenggelam".

\section{METODE}

Penelitian ini dilakukan dengan menggunakan pendekatan kualitatif yang bersifat deskriptif kualitatif. Karena itu, penelitian ini mendeskripsikan tentang karakter tokoh antologi cerpen Mata yang Enak Dipandang karya Ahmad Tohari. Metode kualitatif merupakan metode yang dalam penggunaannya memanfaatkan cara-cara penafsiran dengan menyajikannya dalam bentuk deskripsi (Ratna, 2009:46).

Penelitian ini dilakukan dengan tiga tahapan yaitu prapenelitian, penelitian, dan pascapenelitian. Pada tahap prapenelitian ditentukan sumber data serta topik yang akan dikaji. Pada tahap penelitian dilakukan pengumpulan data yang berupa kutipan kalimat dan analisis data yang berupa karakter tokoh pada tiap-tiap cerpen. Pada tahap pascapenelitian dilakukan penyimpulan hasil analisis data.

Sumber data pada penelitian ini adalah antologi cerpen Mata yang Enak Dipandang Karya Ahmad Tohari. Pengumpulan data dilakukan dengan menggunakan teknik simak, baca, dan catat. Sementara itu, data penelitiannya berupa kutipan kalimat yang menunjukkan karakter tokoh dalam antologi cerpen tersebut.

Pada penelitian ini hanya berfokus pada enam cerpen yang dipilih berdasarkan jumlah tema terbanyak dari lima belas cerpen yang terdapat dalam antologi cerpen Mata yang Enak. Dipandang Karya Ahmad Tohari yaitu tema kemiskinan tentang permasalahan ekonomi. Keenam cerpen itu adalah cerpen "Mata yang Enak Dipandang", cerpen "Bila Jebris Ada di Rumah Kami”, cerpen "Warung Panajem", cerpen "Sayur Bleketupuk", cerpen "Dawir, Turah dan Totol", dan cerpen "Harta Gantungan. Dalam penelitian ini juga hanya memfokuskan pada tiga karakter tokoh ialah, karakter pemarah, peduli dan baik hati.

\section{HASIL DAN PEMBAHASAN}

Pada penelitian yang telah dilakukan terdapat 45 data yang menunjukkan karakter tokoh dengan 28 karakter yang berbeda-beda. Pada cerpen "Mata yang Enak Dipandang" berjumlah 7 data, cerpen "Bila Jebris Ada di Rumah Kami" berjumlah 10 data, cerpen "Warung Panajem" berjumlah 7 data, cerpen "Sayur Bleketupuk" berjumlah 6 data, "Dawir, Turah dan Totol" berjumlah 7 data, dan cerpen "Harta Gantungan" berjumlah 8 data. Berdasarkan hasil analisis ditemukan tiga karakter yang paling dominan. Ketiga karakter itu adalah karakter pemarah, karakter peduli, dan karakter baik hati.

\section{a. Karakter Pemarah}

Karakter pemarah ditemukan pada tiga cerpen, yaitu "Mata yang Enak Dipandang", "Sayur Bleketupuk", dan "Dawir, Turah, dan Tolol". Tokoh Mirta dalam cerpen "Mata yang Enak Dipandang" termasuk tokoh yang berwatak pemarah. Karena pemarahnya itu, ia suka mengumpat, misalnya dengan mengatakan bangsat ketika mengumpat.

"Panas sekali, bangsat!" kata Mirta dengan suara kering dan samar. (MyED:11) 
Penggunaan kata bangsat pada kutipan tersebut menunjukkan bahwa Mirta seorang tokoh pemarah. Hal tersebut terlihat saat Mirta menggunakan kata kasar sebagai bentuk kekesalannya kepada Tarsa sang penuntunnya.

Tokoh Kang Dalbun dalam cerpen "Sayur Bleketupuk"

Kang Dalbun juga termasuk seorang tokoh yang pemarah. Kepada seorang mandor, dia mengatakan bahwa sang mandor sebagai mandor terkutuk, gara-gara membayar buruhannya dengan terlambat, seperti tampak pada kutipan berikut.

"Ini semua gara-gara mandor terkutuk itu," keluh Dalbun sambil keluar. "Apa pun alasan keterlambatannya, hari ini dia jadi mandor yang paling terkutuk" (MyED:105)

Kutipan tersebut menggambarkan tokoh Kang Dalbun pemarah. Hal tersebut terlihat saat Kang Dalbun melampiaskan kemarahannya dengan menggunakan katakata kasar kepada mandornya.

Tokoh Dawir dalam cerpen "Dawir, Turah, dan Totol" juga termasuk tokoh yang berwatak pemarah.

Dawir jadi benci Emak. Dan marah. Maka pagi-pagi selagi Emak masih tidur dempet dengan tukang semir, Dawir terjun dari gerbong yang rusak. Harus terjun karena Dawir masih kecil. Terus menyeberang rel, menyeberang rel lagi. Lalu naik ke sambungan kereta barang yang sudah hampir berangkat. ... (MyED:122)

Kutipan tersebut menggambarkan karakter tokoh Dawir yang pemarah. Hal tersebut terlihat saat dirinya nekat terjun dari gerbong saat Emaknya masih tertidur.

\section{b. Karakter Peduli}

Karakter peduli ditemukan pada cerpen "Bila Jebris ada di Rumah Kami", dan "Harta Gantungan. Pada cerpen "Bila Jebris ada di Rumah Kami" watak perhatian tampak pada tokoh Sar dan Ayah Jebris. Tokoh Sar dalam cerpen "Bila Jebris ada di Rumah Kami”

Sampai demikian jauh, Sar masih bisa menahan kesedihannya. Sar tetap menyokong Jebris dengan beberapa rantang beras jatah setiap bulan. ... (MyED:22-23)

Kutipan kalimat tersebut menggambarkan karakter tokoh Sar yang peduli terhahap Jebris. Ha; tersebut terlihat saat Sar setiap bulannya membatu Jebris dengan memberinya beras.

Tokoh Ayah Jebris "Bila Jebris ada di Rumah Kami” 
"Nak Ratib, sudah dua hari Jebris tidak pulang. Pagi tadi ada orang melihat Jebris di kantor polisi. Dihukum."

"Dihukum?

"Ya. Kalau tidak dihukum, mengapa jebris ada di kantor polisi? Nak Ratib, kasihan Si mendol. Dia tak mau makan dan menangis minta menyusul emaknya. (MyED:27)

Kutipan kalimat tersebut menggambarkan karakter tokoh Ayah Jebris yang peduli akan cucunya yang tidak mau makan karena ibunya belum pulang.

Di dalam cerpen "Harta Gantungan" karakter peduli tampak pada tokoh Markotob dan Para Tetangga. Tokoh Markotob dalam cerpen "Harta Gantungan" termasuk berwatak peduli, seperti tampak pada kutipan berikut ini.

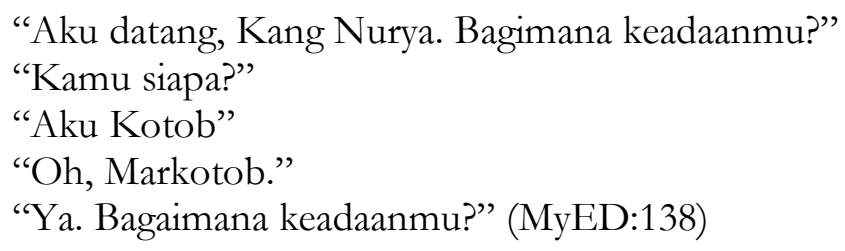

Kutipan kalimat tersebut menggmbarkan tokoh Markotob memiliki karakter yang peduli. Hal tersebut terlihat saat Markotob menanyakan keadaan Kang Nurya sahabat karibnya.

Tokoh Para Tetangga dalam cerpen "Harta Gantungan"

... Perubahannya sangat cepat. Untung ada para tetangga yang setia menunggu Kang Nurya dan memberi makan dan minum. Kang Nurya sudah terlihat parah. Tetapi para tetangga yang menunggu hanya bisa kebingungan karena tak tahu apa yang harus dilakukan selain membei air bila Kang Nurya minta minum. (MyED:138)

Kutipan kalimat tersebut mengambarkan karakter para tetangga yang berada disekita rumah Kang Nurya yang dengan tulus menunggu dan memberi makan dan kinum kepada Kang Nurya yang sedang sakit dan hanya tinggal sendiri di rumahnya.

\section{c. Karakter Baik Hati}

Karakter baik hati ditemukan pada cerpen "Bila Jebris Ada di Rumah Kami" dan "Sayur Bleketupuk". Tokoh Ratib dalam cerpen "Bila Jebris Ada di Rumah Kami" termasuk tokoh berkarakter baik hati.

"Ya. Kakek sudah terlalu lemah. Kakek tinggal saja dirumah. Biar aku yang menyusul Jebris dan bila mungkin membawanya pulang," kata Ratib. (MyED:27) 
Kutipan kalimat tersebut menggambarkan karakter Ratib yang baik. Hal tersebut terlihat saat tokoh Ratib menawarkan dirinya kepada kakek (ayah Jebris) untuk menyusul Jebris karena Ia sudah tua dan lemah.

Tokoh Bu RT dalam cerpen “Sayur Bleketupuk” juga termasuk tokoh yang berkarakter baik hati.

Bu RT percaya. Parsih menelan ludah. Keduanya kemudian berjalan beriringan. Dirumah Bu RT, Parsih melihat Darto dan Darti terlelap dan terkulai di atas karpet. Parsih Hampir menangis. Dia kemudian minta tolong Bu RT menaikkan Darti ke punggungnya. Anak itu tetap lelap, tersampir di punggung Parsih yang berjalan terbungkuk-bungkuk. Darto diurus pula dengan cara yang sama. Kedua anak itu kemudian dibaringkan di tempat tidur yang sama. Mereka sungguh lelap di bawah pengaruh khasiat daun bleketupuk. (MyED:103)

Kutipan kalimat tersebut menggmbarkan kebaikan tokoh Bu RT yang percaya terhadap parsih dan mau membantu Parsih menaikkan anak-anaknya ke punggungya.

Tokoh Dawir dalam cepen "Dawir, Turah, dan Totol"

... Dan pada jam lima sore ini Totol memakai baju baru, sepatu baru, pakai topi bertulis marinir, sudah makan roti enak sampai kenyang. Totol juga sudah punya senapan maninan pakai baterai. Bila pelatunya ditarik senapan itu akan berbunyi tret-tetetetetetet sambil menghampurkan cahaya merah dari moncongnya. Memang Dawir sudah mengancam, sekali punya uang dia akan beli roti enak.juga beli senapan yang pakai baterai untuk Totol. (MyED:123)

Kutipan kalimat tersebut menggambarkan tokoh Dawir memiliki karakter yang baik. Hal tersebut terlihat ketika Totol memakai baju baru, sepatu baru , topi marinir, makan roti enak dan juga mainan senapan yang dibelikan Dawir pada Totol saat dirinya punya uang.

Tokoh Pak RT dalam cerpen "Harta Gantungan”

Anak Kang Nurya menunduk. Kemudian dengan senyum malu-malu dia berkata, "Kerbau itu jelas akan saya jual. Sebagaian uangnya akan saya serahkan sebagai ganti biaya yang telah dikeluarkan oleh para tetangga..."

"Tidak. Kami tidak meminta ganti," potong Pak RT yang hadir di antara kami. Semua orang setuju. Mata Wardi melebar dan berkaca-kaca. Tangisnya terasa hampir pecah. (MyED:140-41)

Kutipan kalimat tersebut menggambarkan tokoh Pak RT memiliki karakter yang baik. Hal tersebut terlihat saat Pak RT menolak meminta ganti biaya kepada Wardi anak Kang Nurya saat mengurus jenazah ayahnya. 


\section{Implikasi dalam Pembelajaran Bahasa Indonesia di SMA}

Dalam pembelajaran Bahasa Indonesia terkait dengan implikasinya terhadap hasil penelitian karakter tokoh dalam antologi cerpen Mata yang Enak. Dipandang Karya Ahmad Tohari adalah dapat diimplikasikan dalam pembelajaran bahasa Indonesia di SMA, yaitu pada kelas XI semester II (genap) dengan Kompetensi Dasar 3.9 menganalisis unsur-unsur pembangun dalam kumpulan cerita pendek, dengan pokok bahasan tentang unsur intrinsik tokoh dalam cerpen.

Penelitian ini juga dapat menambah minat belajar siswa terhadap pembelajaran sastra dalam mengapresiasi sebuah karya sastra dan siswa dapat belajar memahami tentang bagaimana karakter yang seharusnya diteladani dan diterapkan dalam kehidupan sehari-hari.

\section{PENUTUP}

\section{Kesimpulan}

Berdasarkan hasil analisis penelitian dan pembahasan tentang karakter tokoh dalam antologi cerpen Mata yang Enak Dipandang karya Ahmad Tohari memiliki karakter yang berbeda-beda pada tiap tokohnya yang dapat menghidupkan serta memberikan nyawa dalam cerita dalam cerpen-cerpennya sehingga tampak hidup layaknya kehidupan nyata.

Data yang ditemukan terdapat 45 data yang menunjukkan karakter tokoh dengan 28 karakter yang berbeda-beda. Pada cerpen "Mata yang Enak Dipandang" berjumlah 7 data, cerpen "Bila Jebris Ada di Rumah Kami" berjumlah 10 data, cerpen "Warung Panajem" berjumlah 7 data, cerpen "Sayur Bleketupuk" berjumlah 6 data, "Dawir, Turah dan Totol" berjumlah 7 data, dan cerpen "Harta Gantungan" berjumlah 8 data. karakter tersebut yaitu karakter pemarah yang terdapat dalam "Mata yang Enak Dipandang", "Sayur Bleketupuk", dan "Dawir, Turah, dan Tolol", karakter peduli yang terdapat dalam cerpen "Bila Jebris ada di Rumah Kami", dan "Harta Gantungan", dan Karakter baik hati yang terdapat dalam cerpen "Bila Jebris Ada di Rumah Kami” dan "Sayur Bleketupuk".

\section{Saran}

Berdasarkan hasil penelitian diharapkan mampu memberikan wawasan dan pengetahuan bagi pembaca dan bagi guru khususnya dalam pemilihan materi sebagai bahan ajar mengenai pembelajaran karakter.

\section{DAFTAR PUSTAKA}

Nugrahaeni, Sri Aninditya. 2012. Pengajaran Bahasa Indonesia Berbasis Karakter. Yogyakarya: Mentari Pustaka.

Nurgiantoro Burhan. 2013. Teori Pengkajian Fiksi. Yogyakarta: Gadjahmada University Press.

Ratna, Nyoma Kutha. 2009. Teori, Metode, dan Teknik Penelitian Sastra. Yogyakarta: Pustaka Pelajar.

Stanton, Robert. 2012. Teori Fiksi. Yogyakarta: Pustaka Pelajar.

Sudjiman, Panuti. 1991. Memahami Cerita Rekaan. Bandung: Pustaka Jaya.

Wiyanto, Asul. 2005. Kesusastraan Sekolah Penunjang Pembalajaran Babasa Indonesia SMP dan SMA. Jakarta: Grasindo Anggota Ikapi. 
Karakter Tokoh Dalam Antologi Cerpen Mata yang Enak Dipandang...

Tohari, Ahmad. 2015. Mata yang Enak Dipandang. Jakarta: Garamedia Pustaka Utama. 